\title{
The figure of the translator revisited: a theoretical overview and a case study
}

\author{
Lieven D'hulst
}

KU Leuven

\section{Openings}

In 2009, the Finnish scholar Andrew Chesterman announced the birth of a new branch in translation studies: "... within the field of Translation Studies we may be witnessing the development of a new subfield, a new branch. I suggest we could call this TranslaTOR Studies" (2009: 13). The main object of this subfield, as understood by Chesterman, would be to assemble all sorts of "research which focuses primarily and explicitly on the agents involved in translation, for instance on their activities or attitudes, their interaction with their social and technical environment, or their history and influence" (20). Such coverage entails a vast programme. But even to deal with a single aspect seems a boundless undertaking because categories such as the "agents involved in translation", or by the same token "their activities or attitudes", necessarily include more than translators or translating proper. In addition, all three domains are to some extent entangled as one may easily understand: attitudes depend on environment, and history covers activities and attitudes as well as social and technical environment.

Yet, without fully endorsing this program, I consider the presuppositions underlying it quite interesting esp. against the historical background of the recent and intense interest towards translators as noted by Chesterman. In other words, why did scholars at some point get interested in the figure of the translator? It seemingly fills up a void space in the programme of translation studies as it was designed in the early 1970's, notably by James Holmes (1972/1988), whose famous "map" is referred to by Chesterman.

In order to become a full-fledged discipline, blind spots should disappear on the map, turning it into the mirror of a proper and autonomous discipline. But how specific and autonomous is translation studies? The gradual extension of the research domain has been accompanied by the search for adapted concepts and methodologies, many of which have precisely been borrowed from neighbouring disciplines of the social sciences (linguistics, sociology, anthropology, law) and nowadays also by other ones, such as psychology, economy and even neurology. This evolution has yielded no doubt original insights, but did it support the legitimacy claim of translation studies (E. Brems et al. 2014)? To put it rather bluntly: to what extent do we need translation studies to study translation?

Let me rephrase the topic in the form of a question: are translator studies part of translation studies (or solely of translation studies)? In order to answer this question, I should like to follow two paths: the first is a short overview of recent theoretical work on the translator category; the second is a presentation of a historical case study. Both paths take the form of a spiral or helix movement. The first spiral (moving from general to particular) presents three theoretical routes. It opens with a view on social discourse in which the translator is but one of many categories or components, and then moves on with a more restricted approach of the different contents or definitions of the 
Convergences francophones $2.2(2015): 1-11$

http://mrujs.mtroyal.ca/index.php/cf/index

translator concept, ending up with a specific focus on translator's voice in the text. The second spiral is historical and offers a view on a specific historical setting in which the concept of the translator needs further clarification and contextualization: it deals with a $19^{\text {th }}$ century Belgian translator-mediator. I will hopefully end up with some suggestions for further research.

\title{
Theoretical routes
}

\section{Discourse analysis and the translator}

We are no doubt quite familiar in translation studies with the pervasive technique of splitting up the constituents of translation processes. Think of the mainstream models of translational communication, which are based on the principle of replication of the famous jakobsonian model of communication (1960): Author ${ }^{1}-$ Text $^{1}-$ Reader $^{1} / /$ Author $^{2}-$ Text $^{2}-$ Reader $^{2}$. This 'trinitarian' model of the translation process has predominantly focused on the relations between Text $^{1}$ and Text ${ }^{2}$ and therefore has been less concerned by the understanding of Author ${ }^{1}$ and Author ${ }^{2}$, for example . $^{1}$

Critical discourse analysis, at least in its textually oriented version as shaped by Norman Fairclough and his colleagues, has developed a more comprehensive view of verbal communication, in which discourse is part of a social practice, i.e.

\begin{abstract}
... an articulation of diverse social elements within a relatively stable configuration, always including discourse. Let us say that every practice includes the following elements: Activities, Subjects, and their Social Relations, Instruments, Objects, Time and Place, Forms of consciousness, Values, Discourse. (Fairclough 2001: 3)
\end{abstract}

He continues: "These elements are dialectically related ... That is to say, they are different elements but not discrete, fully separate, elements. There is a sense in which each 'internalizes' the others without being reducible to them" (3). As a consequence, texts as constituents of discourse are more than finite products occupying fixed places between equidistant subjects such as authors and readers.

The preceding implies also that the relations operating between subjects like authors and translators, or objects like source texts and target texts, are dialectical in their turn. At first sight, there should be nothing odd about such a hypothesis: we all know that authors may interact with the translators of their work, that authors may write about translators and vice versa or that translators may turn into authors. We also know that authors may become self-translators or write in two languages. And we know how dynamic the relations are between writing and translating in the world of multimedia.

\footnotetext{
${ }^{1}$ Or by the definition or circumscribing of what contexts and codes are and how one should define their correlates at the other end of the process. The issue of context has been extensively dealt with by Martin Jay (2011).
} 
Convergences francophones 2.2 (2015) : 1-11

http://mrujs.mtroyal.ca/index.php/cf/index

To sum up: all constitutive elements of discourse are interdependent units, which means they may enter combinations both like fixed pieces with fixed roles on a chess board and like flexible, open or so to speak permeable structures, whose changing and shared roles depend on numerous conditions that need to be taken into account. In other terms: subjects such as authors and translators (or activities such as translating and writing) become so within the constellation of relations they forge with other elements, which precisely turn them into authors and translators (or into activities such as translating and writing, and into all intermediate forms). To put it differently, it is precisely because other transfer techniques co-occurred - already since Antiquity - with translation that it became imperious but also possible to label the latter as a distinct form and translators as a specific subgroup of mediators. But the frontiers are unstable, as are the conditions under which translation operates. One could imagine to leave things at that point and adopt a radically relativistic viewpoint.

\section{The "translator" concept}

Others have nevertheless tried to fill the concept of the translator with some more specific content. No doubt that this second route, although smaller in scope, has attracted far more scholarly attention. One could distinguish here three more or less distinct foci: a biographical person, a socio-professional instance, and a textual instance. I will shortly present the first two ones, and will linger a bit longer at the last one.

Studying the translator as a person, means to reflect on his/her background, education, social and professional activities, etc. There is a sensible amount of research available on translators' lives and activities, either monographies focussing on major figures active in more than one domain, such as Caxton (Deacon 1976) or Tyndale (Daniell 1994) or collections of essays or "portraits" assembling professionals in a more or less exemplary way (Delisle 1999 and 2002, Whitfield 2006). Few generalizing statements on the specifics of translators' trajectories seem to be allowed, although the genre of the biography may help to overcome traditional stereotypes such as invisibility, betrayal or subservience.

Studying the translational function means to approach the translator as a more or less institutionalized instance in the cultural field: more, when the instance is taken as a professional category (Pym et al. 2012), covering "academic qualifications, professional certifications, membership of associations and years of experience"; less, when it deals with occasional or non-professional translation practices, as often occurs in community translation (O'Hagan 2011), crowdsourcing translation (Sutherlin 2013), fansubbing and more modes of participatory media. Recent research has intensively invested in functional and ethical aspects of translator's approach, be it that civil and legal aspects have been foregrounded (e.g. translator's rights, e.g. S. Basamalah 2009), or that scholars have taken interest in censorship and power issues (e.g. F. Billani 2014). 
Convergences francophones 2.2 (2015) : 1-11

http://mrujs.mtroyal.ca/index.php/cf/index

An important theoretical achievement is the well-known "habitus"concept adapted to the translator category by Daniel Simeoni (1998), as "the elaborate result of a personalized social and cultural history" (32), the translator being "a cultural mind moulded by the social environment and incorporated in the translator's act" (32.). Other well-received approaches are Justa HolzMänttäri's "Handlungstheorie", stressing the expert role and specific action of translators in a complex network of actions through which the customer's expectations are achieved (1984: 87), and Bruno Latour's "Actor-NetworkTheory", according to which actors (human and non-human) are such by virtue of their relations, while "translation" (in a metaphorical sense, though) becomes a binding element between actors (Buzelin 2005).

Conceived as a textual instance, the translator has also attracted a great deal of academic interest in recent decades. One may recall the research conducted by Jiří Levý (1963) and others on the artistic and ideological beliefs and attitudes of the translator exhibited by the constitutive and individual lexico-semantic, syntactic, prosodic etc. shifts taking place between original and translation. Also, descriptive translation studies (from the late 1970's on) has put more emphasis on the stylistic and ideological norms of the translator's "behaviour" or "strategy" (i.e. terms which at that time carried largely metaphorical meanings).

Yet, somehow, this third instance - also called the "figure" of the translator (Skibińska 2012) - has itself remained a rather complex if not ambivalent category, since most of the recent research follows two separate paths: the first one looks at the way the translator is represented within fictional or autobiographical works, either as a narrator or as a character: cf. Ingeborg Bachmann's Simultan (1972), José Carlos Somoza's La caverna de las ideas (2000), John le Carré's The Mission song (2006), Jacques Poulin's La traduction est une histoire d'amour (2006), and many hundreds more in many languages. In the same vein, one may refer to movies like The Interpreter, Lost in translation or Babel, as well as to songs, paintings, sculptures, photography, etc. (Kaindl \& K. Spitzl 2014). Such scenographies often contain a correction, criticism or parody, of existing views on the translator, which is probably one of the reasons why many translators, self-translators or bilingual writers have been indulging with them. The second path focuses on the discursive forms and functions taken by translational enunciation in translations by occupying their two main discursive spaces, i.e. the paratext (prologues, prefaces, postfaces, footnotes, etc.) and the translated text. Since a few years, this path has given way to a rapidly expanding subfield, opening space for debates about the meaning of the concept of translator's (or translatorial) enunciation and about the many aspects covered by the many names that should be given to this enunciator: is he/she a voice, a point of view, an ethos, a posture, an image? Let us now concentrate on this issue.

\section{The enunciator}

It should not come as a surprise that the study of the translator's enunciation within the textual space originates in the translation-as-communication 
Convergences francophones 2.2 (2015) : 1-11

http://mrujs.mtroyal.ca/index.php/cf/index

approach. More specifically, it is rooted in the classic a priori distinction between the author and the translator. Let me give some examples. While attempting to achieve a theoretical definition of what she calls the "voice" of the translator in narrative prose, Giuliana Schiavi takes as a starting point the well-known model of narrative designed by the American narratologist Seymour Chatman (1990), this latter model being based on the communication one ( qtd. in Schiavi 1996: 10):

\author{
Narrative text \\ real author... ...implied author - narrator - narratee - implied reader... ...real \\ reader
}

This model is then adapted in order to account for translation enunciation (Schiavi 1996: 14):

R.A..|..I.A. - -Nr-Ne-I.R./real translator- -implied translator-Nr-Ne-I.R. of translation..| R.R.

$$
\begin{array}{ll}
\text { R.A. = real author } & \mathrm{Ne}=\text { narratee } \\
\text { I.A. = implied author } & \text { I.R. = implied reader } \\
\mathrm{Nr}=\text { narrator } & \text { R.R. = real reader }
\end{array}
$$

The model invites for further thought: it assumes for instance that translation duplicates or mirrors authorial and lectorial categories, a mirroring that would be concomitant with the ST-TT duplication, although little evidence is given for such an assumption: Author $-\mathrm{ST}-$ Reader SC / =?/ Translator $-\mathrm{TT}-$ Reader TC. One may also note that it takes the concept of "voice" in the genettian sense, voice being a metaphor for the narrating instance, yet for other narratologists it includes what Genette calls "mood" (perspective and distance as exemplified by focalization), and as we know focalization is something that also hinges upon characters. The latter semantic extension of the concept of voice suggests there are text-internal links between the narrators' voice and other aspects of a text.

A number of scholars have attempted to unravel, on the basis of sets of translations, the textual expressions taken by the voice concept. For example, Charlotte Bosseaux (2007) has developed a method to analyse narrative viewpoint applied to the French translations of Virginia Woolf. The major grammatical categories she makes use of are: deixis, personal pronouns, verbs and modal adverbs, free indirect speech (the mixing of the voices of narrator and character). Her method has been able to reveal indeed a number of shifts, even to reconstruct the features of a different narrative viewpoint, without however coming to the conclusion that one may simply differentiate between two voices on the narratorial axis. Be that as it may, her study is also food for further thought. One may wonder, for instance, whether a larger research programme could answer questions with larger historical impact such as: is the narrative voice unique (i.e. dependent on the text) or recurrent (dependent on the translator or on groups of translators of Woolf, of novels of that time, of English-language novels)? Does it also depend on editorial, cultural or other constraints? 
Convergences francophones 2.2 (2015) : 1-11

http://mrujs.mtroyal.ca/index.php/cf/index

A new and promising domain of study is the genesis of translating processes based on manuscripts, variants and revisions of printed versions. It gives insight into the principles underlying decision making (a.o. J. Munday 2013). In addition, the study of the emergent and changing poetics of bilingual authors and self-translators has given way to innovative views on the complex intertwining between writing and translating with authors such as Samuel Beckett and Nancy Huston (Montini 2007; Merrigan 2013).

To sum up the results of the overview of the three theoretical routes: it seems that more research is needed to correlate the person, the function and the textual expressions when dealing with the voice concept. In addition, since most of the categories mentioned change through time and space, we also need to describe these changes and be able to explain when and where the translator category changes the way it does. It is quite obvious, indeed, that every epoch and culture has its favourite instances, meanings, roles, and representations of the translator. History may thus become of crucial importance here. And it will also raise further tricky conceptual and methodological issues, as will be exemplified by the following example.

\section{Octave Delepierre: a Belgian $19^{\text {th }}$ century mediator}

A historical viewpoint needs adaptation or completion of pre-established concepts. What follows is part, concerning one translator, of an ongoing project conducted at KU Leuven (2011-2015) on "Customs officers or smugglers? the mediating role of intercultural actors within Belgium and between Belgium and France (1850-1920)". It brings together translation scholars, cultural historians and literary historians, with a focus on $19^{\text {th }}$ and early $20^{\text {th }}$ century (D'hulst et al. 2014).

$19^{\text {th }}$ century Belgium is a young and heterogeneous culture made up by two language communities. Nevertheless, the very idea of a unified Belgian culture is largely shared by the cultural elites of both communities and strongly supported by official institutions. As a result of the tension between the factual heterogeneity and the imagined homogeneity, intense mediating activities are launched in view of enriching the repertoires of several cultural practices such as literature and art history in the two languages. These activities are assumed by culture mediators, complex multi-layered figures taking care of all sorts of processes: translation, borrowing, plagiary, copying, adaptation, etc. (in addition to non-verbal forms of transfer in the domains of music, architecture, art exhibition, etc.). Even when restricting the scope to verbal transfer only, mediators cover more modalities than so-called natural interlingual translation: intralingual translation, paraphrase, compilation, summary, reviewing, parody and plagiary applied to a wide array of poems, novels, song texts, etc.

Octave Delepierre is a typical example of Belgian $19^{\text {th }}$ century mediation. Born in Bruges in 1802 within a bourgeois family, he studies law at the University of Ghent, establishes as an advocate in Brussels, then for some twenty years is an archivist and librarian in Bruges. In 1849, he is appointed Belgian secretary of legation in London, a position held for many years, to which is added later on the position of consul-general for Belgium in London. 
Convergences francophones 2.2 (2015) : 1-11

http://mrujs.mtroyal.ca/index.php/cf/index

On the cultural side, he is a member of numerous learned societies in Belgium and England, in particular the secretary of the famous Philobiblion society of London. Delepierre is the author, translator, and editor of more than fifty works, mostly composed in French, some being directly written in English.

The discursive mediating activities take up by Delepierre are amazingly diverse, as may be attested by a list of the categories of publications and their intended public, although it should be stressed that these activities mix different modalities.

- National history: La Belgique illustrée par les sciences, les arts et les lettres (Brussels, 1840). The intended addressees are probably French and Belgian.

- Literary history: Histoire littéraire des fous (London 1860), A sketch of the history of Flemish literature (London, 1860), Les supercheries littéraires (London 1872). The intended public is British and French.

- Language history: De l'origine du flamand, avec une esquisse de la littérature flamande et hollandaise, d'après l'anglais de J. Bosworth (Tournai, 1840). Intended public: international.

- Art history: Galerie d'artistes brugeois, ou biographie concise des peintres, sculpteurs et graveurs célèbres de Bruges (Bruges, 1840). The intended public is international.

- Poetical and narrative imitations and rewritings: Heures de loisir. Essais poétiques (Ghent, 1829), a volume of poetry based on Byron, Lamartine but also on narrative prose such as Le lépreux de la cité d'Aoste, a poetical imitation of a dialogue by cf. X. de Maistre. The intended public is Belgian.

- Translation proper, of which several types or modes have to be distinguished. First, interlingual translation of Latin chronicles into French, intended for a mainly Belgian readership (Vision de Tondalus, récit mystique du douzième siècle, Mons, 1837, Philippide de Guillaume-Le-Breton, Bruges, 1841). Secondly, mediated or indirect translation, a category that covers a.o. the following two types: (1) translation from ancient Flemish into French, e.g. the Aventures de Tiel Ulenspiegel (Bruges 1835) and Le Roman de Renard (Brussels 1837), aimed at a Belgian and French public; (2) translation from Flemish into French into English: Old Flanders, or Popular traditions and legends of Belgium (London 1845), which is a retranslation of Chroniques, traditions et légendes de l'ancienne histoire des Flamands (Bruges 1834), a collection of short narrative complied and translated by Delepierre and which is by itself a translation of unspecified Flemish source texts. The intended public is Belgian and British. Finally, Delepierre also co-translates novels, such as the Heiress of Bruges by Thomas Grattan, translated into French by Delepierre and revised by Henri Moke (Paris 1831). The intended public is seemingly French and Belgian.

- Anthologies of an array of works belonging to lower genres, such as rebus, centons and parodies, e.g. Recueil d'opuscules et de fragments en vers patois, extraits d'ouvrages devenus fort rares (Paris 1839), Macaronéana ou Mélanges de littérature macaronique (Brighton 1852), La parodie chez les Grecs, chez les Romains et chez les Modernes (London 1870), Essai historique et bibliographique sur les rebus (London, 1870). The intended public is French and British. 
Convergences francophones 2.2 (2015) : 1-11

http://mrujs.mtroyal.ca/index.php/cf/index

- Forgery of fictional prose by contemporary Flemish writers Conscience and De Laet, in translated excerpts published in the already mentioned anthology Old Flanders, or Popular traditions and legends of Belgium. The intended public is British ${ }^{2}$.

In addition to the long list of discursive mediating activities, Delepierre undertakes an array of institutional mediating activities, such as a tourist guide (in Bruges), a secretary of literary societies (in Bruges, Mons and London), a curator (of the Belgian pavilion of the "exposition universelle" of London in 1862), and even a publisher (including of some of his own work).

How should one explain these multiple cultural roles that stretch far beyond a theoretical definition of a "translator"? Belgian $19^{\text {th }}$ century culture being quite young, it does not yet establish itself as an independent field (as the major neighbouring countries achieved some decades earlier), and thus remains quite dependent on official institutions. In contrast with France, where the author has gained autonomy, prestige and a superior status compared to the translator's, and where literary activities strongly departed from translational ones, Belgian culture lacks a clear task distribution and hierarchy between instances such as authors, translators, historians, public officers, publishers. In addition, Belgian culture is considered a marginal one in comparison with France, and most of its production confines to lower reproductive practices such as translation, rewriting, editing, teaching, assumed by actors that are themselves marginal literary figures in comparison with their French counterparts. By the way, the latter are massively imported in Belgium (often via pirate editions).

Still, the intense mediating activities by Belgian actors yield strong effects: first, they contribute to the international outreach of Belgian culture paving the way for later generations of Belgian authors. Secondly, they firmly establish the cultural stereotypes by which nations get identified and recognized: the medieval and baroque painters, the flat landscapes and grey North Sea, but also the mastery of languages, the quality of translating and mediating. More scholarly work needs to be done, notably on the institutional side of Delepierre's action, such as a reconstruction, via the study of letters, testimonies, reviews, etc., of his network of relations and of the rationale of the relations between his intracultural and intercultural modes of agency: within Belgium and from Belgium to Paris, London, and back. But so far, it is clear that if one wishes to understand the proper place of the translator category, the better option is perhaps to integrate it into a new sort of "mediator studies".

\section{Epilogue}

I hope to have been able to show that the issue of the translator may adequately be approached from more than one angle: theoretical as well as historical ones, broad as well as small ones. The complexities of translating and the translator may even be grasped by the unit of the single work as may be exemplified by

\footnotetext{
${ }^{2}$ Obviously, Delepierre was unaware of the fact that the Flemish authors would discover the forgery.
} 
Convergences francophones $2.2(2015): 1-11$

http://mrujs.mtroyal.ca/index.php/cf/index

represented translation in fiction, since the macrocosm is contained by the microcosm (as well as the other way round). Fictional translators as characters (or narrators), as well as the act of translating, the reading, publishing of translation, in short the entire program of what Chesterman called translator studies may find a place in a single literary work. In turn, this work is but a small part of the complex act of mediation, in which translators operate next to other mediators. In both cases the frontiers of the translator category have more than ever become fuzzy.

Such small intellectual exercises are lessons in modesty. There is no single highway at our disposal to grasp the translator category. In addition, to approach the figure of the translator, we should not give too much weight to theoretical models, nor should we consider human experiences (translations) and instances (translators) as yardsticks for the validity of theories. Also, we need to find the right balance between theory and history. In my view, more history is needed, that should bring more information about the different facets of the figure of the translator in time and space. Hopefully, in the longer run, we might acquire a more refined view on all the aspects involved by the category translator. But I am not sure that this knowledge will still fit the discipline we nowadays call "translation studies". Should that be a problem? As Clifford Geertz reminds us, ethnographic description is "thick description", and perhaps the translation scholar dealing with a subject like theorizing the translator or analysing voice in translation finds himself/herself in a similar position as the ethnographer facing a "multiplicity of complex conceptual structures, many of them superimposed upon or knotted into one another, which are at once strange, irregular, and inexplicit, and which he must contrive somehow first to grasp and then to render" (1973). There is a long way to go... 
Convergences francophones 2.2 (2015) : 1-11

http://mrujs.mtroyal.ca/index.php/cf/index

\section{Bibliography}

Basamalah, Salah. Le droit de traduire. Une politique culturelle pour la mondialisation. Arras-Ottawa: Artois Presses Université; Les Presses de l'Université d'Ottawa, 2009.

Billani, Francesca, ed. Modes of Censorship: National Contexts and Diverse Media. London: Routledge, 2014.

Bosseaux, Charlotte. How does it Feel? Point of View in Translation. The Case of Virginia Woolf into French. Amsterdam-New York, NY: Rodopi, 2007.

Brems, Elke, Reine Meylaerts \& Luc Van Doorslaer, eds. The Known Unknowns of Translation Studies. Amsterdam-Philadelphia: John Benjamins, 2014.

Buzelin, Hélène. "Unexpected Allies: How Latour's Network Theory Could Complement Bourdieusian Analyses in Translation Studies." The Translator 11:2 (2005): 193-218.

Chatman, Seymour. Coming to Terms: The Rhetoric of Narrative in Fiction and Film. Ithaca (NY): Cornell University Press, 1990.

Chesterman, Andrew. "The Name and Nature of Translator Studies." Hermes Journal of Language and Communication Studies 42 (2009): 13-22.

Daniell, David. William Tyndale: a Biography. London: Yale University Press, 1994.

Deacon, Richard. A Biography of William Caxton, the First English Editor: Printer, Merchant and Translator. London: Muller, 1976.

Delisle, Jean, ed. Portraits de traducteurs. Arras-Ottawa: Artois Presses Université; Les Presses de l'Université d'Ottawa, 1999.

---. Portraits de traductrices. Arras-Ottawa: Artois Presses Université; Les Presses de l'Université d'Ottawa, 2002.

D'hulst. Lieven. Essais d'histoire de la traduction. Avatars de Janus. Paris: Classiques Garnier, 2014.

D'hulst, Lieven, Maud Gonne, Tessa Lobbes, Reine Meylaerts \& Tom Verschaffel. "Towards a multipolar model of cultural mediators within multicultural spaces. Cultural mediators in Belgium (1830-1945)." Revue belge de philologie et d'histoire 92 (2014):1255-75.

Fairclough, Norman. "The dialectics of discourse." Textus 14:2 (2001): 3-10.

Geertz, Clifford. "Thick Description: Toward an Interpretive Theory of Culture" [1973]. Yvonna S. Lincoln \& Norman K. Denzin, eds. Turning Points in Qualitative Research. Tying Knots in a Handkerchief. Walnut Creek, CA: AltaMira Press, 2003, 143-68.

Hermans, Theo. "The Translator's Voice in Translated Narrative." Target 8:1 (1996): 23-48.

---. "Old Flanders, Octave Delepierre en het vertalen." Verslagen \& Mededelingen van de KANTL 122:1 (2012); 39-104.

Holmes, James S. "The Name and Nature of Translation Studies." Translated!: Papers on Literary Translation and Translation Studies. Amsterdam: Rodopi, 1872/1988, 67-80.

Holz-Mänttäri, Justa. Translatorisches Handeln. Theorie und Methode. Helsinki: Suomalainen Tiedeakatemia, 1984. 
Jakobson, Roman. "Linguistics and Poetics." Thomas Sebeok, ed. Style in Language. Cambridge, MA: M.I.T. Press, 1960: 350-77.

Jay, Martin. "Historical Explanation and the Event: Reflections on the Limits of Contextualization." New Literary History 42:4 (2011): 557-71.

Kaindl, Klaus \& Karlheinz Spitzl, eds. Transfiction: Research into the realities of translation fiction. Amsterdam-Philadelphia: John Benjamins, 2014.

Latour, Bruno. Reassembling the Social - An Introduction to Actor-NetworkTheory. Oxford: Oxford University Press, 2005.

Levý, Jiří. Die literarische Übersetzung: Theorie einer Kunstgattung. Frankfurt am Main: Athenäum Verlag, 1969.

Merrigan, Klaartje. "La pseudo-traduction chez Nancy Huston: vers une poétique de l'absence." Les Lettres romanes 67. 3-4 (2013): 463-77.

Montini, Chiara. "La bataille du soliloque". Genèse de la poétique bilingue de Samuel Beckett (1929-1946). Amsterdam/New York: Rodopi, 2007.

Munday, Jeremy. "The Role of Archival and Manuscript Research in the Investigation of Translator Decision-Making." Target. International Journal of Translation Studies 25.1 (2013): 125-39.

O'Hagan, Minako. "Community Translation: Translation as a social activity and its possible consequences in the advent of Web 2.0 and beyond." Linguistica Antverpiensia 10 (2011): 11-23.

Pym, Anthony, François Grin, Claudio Sfreddo and Andy L.J. Chan. The Status of the Translation Profession in the European Union. S. 1.: European Commission, 2012.

Schiavi, Giuliana. "There Is Always a Teller in a Tale." Target 8.1 (1996): 121.

Simeoni, Daniel. "The pivotal status of the translator's habitus." Target 10.1 (1998): 1-39.

Skibińska, Elżbieta, ed. Figure(s) du traducteur. Romanica Wratislaviensia, LIX, 2012.

Sutherlin, Gwyneth. "A voice in the crowd: Broader implications for crowdsourcing translation during crisis." Journal of Information Science 39.3 (2013): 1-13.

Whitfield, Agnes, ed. Writing Between the Lines: Portraits of Canadian Anglophone Translators. Waterloo: Wilfrid Laurier University Press, 2006. 